\title{
NON-MONOTONOUS DEPENDENCES OF THIN FILM SURFACE ROUGHNESS ON SUBSTRATE TEMPERATURE AND DEPOSITED ATOM FLUX
}

\author{
R. Čerapaitè-Trušinskienè ${ }^{\mathrm{a}, \mathrm{b}}$ and A. Galdikas ${ }^{\mathrm{a}, \mathrm{b}}$ \\ ${ }^{a}$ Physics Department, Kaunas University of Technology, Studentu 50, LT-51368 Kaunas, Lithuania \\ E-mail: reda.cerapaite@ stud.ktu.lt \\ ${ }^{\mathrm{b}}$ Department of Physics, Mathematics and Biophysics, Kaunas University of Medicine, Eiveniu 4, LT-50009 Kaunas, \\ Lithuania
}

Received 13 March 2008; revised 21 August 2008; accepted 18 September 2008

\begin{abstract}
Experimentally observed non-monotonous dependences of thin films surface roughness on substrate temperature and flux of deposited atoms are analysed by kinetic rate equation model. The modelling results show good qualitative agreement with the experiment and explain an unusual phenomenon of surface roughness. It is shown that non-monotonous dependence of surface roughness on substrate temperature and deposition flux is determined by the size of islands and diffusivity of atoms on the surface. From present analysis it follows that the formation mechanisms of non-monotonous dependences of the surface roughness on temperature and deposition flux are of different origin. The mechanisms are qualitatively analysed in the present paper.
\end{abstract}

Keywords: surface roughness, island films deposition, surface diffusion, kinetic modelling

PACS: $81.15 . \mathrm{Aa}, 82.20 . \mathrm{Wt}$

\section{Introduction}

The surface roughness is one of the most important parameters of thin films that influence growth properties of the deposited films. Smooth surfaces lead to a more uniform, fine grain structure, while rough surfaces with peaks, valleys, and other defects act as either preferred sites or lead to shadowing of the adatoms and more columnar-type microstructure [1]. The morphology and surface roughness of growing thin film can be influenced by substrate relief (the substrate relief influences the cluster formation on the surface) [2], deposited material lattice mismatch with substrate [3], substrate surface crystallographic direction (the diffusion length of adatoms and diffusion coefficient depend on surface direction) [4], etc. The surface roughness depends on many factors during process of thin film deposition. The fundamental physical processes, such as adsorption, desorption, nucleation, surface diffusion, coalescence of islands, heterogeneous reaction, etc., are being observed in early thin film growth stages. All these processes take place simultaneously and determine the surface morphology of the film. Moreover, these processes proceed differently for different materi- als and depend on the process conditions. Various surface roughness dependences on different technological parameters, such as substrate temperature, ion energy, flux of arriving atoms, etc., have been investigated experimentally [5-12]. The analysis of different factor influence on the surface roughness has shown that the surface roughness can decrease, increase, or stay constant depending on considered interval of atom energies.

There are many works where non-monotonous surface roughness dependence on the substrate temperature [5-8] and the flux of arriving atoms [11] have been observed. Several examples are presented in Fig. 1 $[6,11]$. In many papers published recently the authors present different explanations of the formation of this minimum point. Earlier it has been shown by Monte Carlo calculations [13] that the diffusion ability of adatoms increases with increase of the substrate temperature and more adatoms can be activated to diffuse and fill in the inner voids of the film. Then surface roughness decreases with temperature. However, when the temperature becomes too high the diffusivity of atoms is very high so that some of them can jump onto the top of upper layer. As a result the surface roughness increases with temperature again [13]. Authors of the 


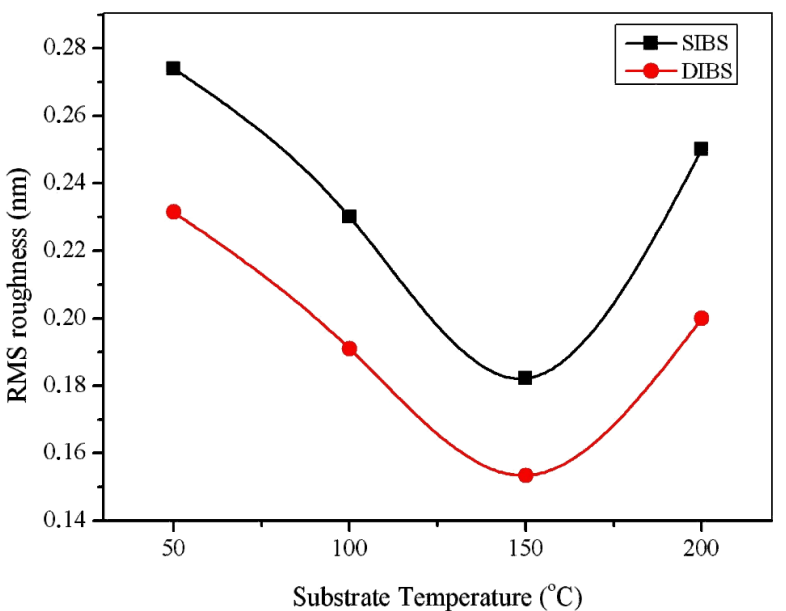

(a)

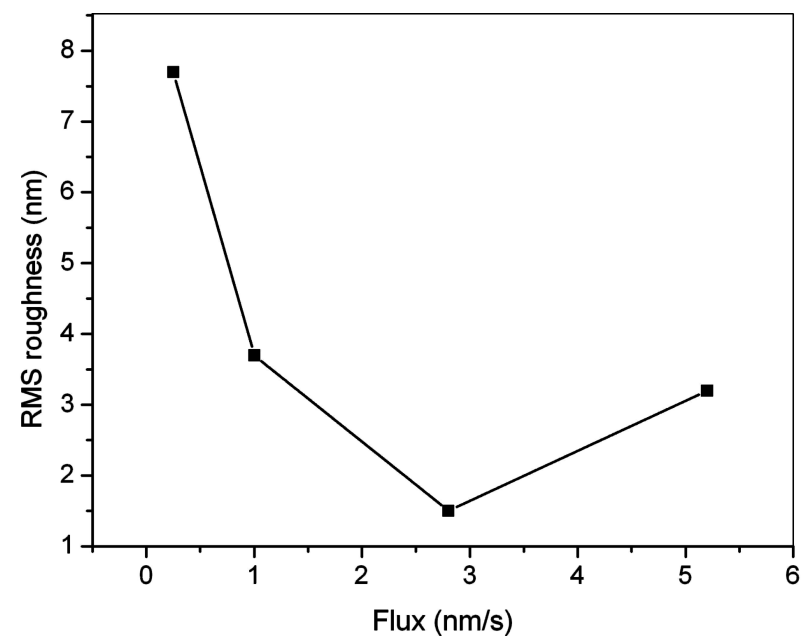

(b)

Fig. 1. Dependence of surface roughness on the substrate temperature and on the flux of arriving atoms: (a) experimental data, obtained by Yoon et al. [6] (SIBS: single ion beam sputter deposition, DIBS: dual ion beam sputter deposition), (b) experimental data, obtained by Dumont et al. [11].

Fig. 1(b) [11] explain non-monotonous dependence of the surface roughness on the deposition rate using the relation between the average distance between islands and critical island radius at which a second layer nucleates on the top of these islands (the so-called "TDT approach" theory). The layer-by-layer growth is observed and the surface becomes smoother, if critical island radius is larger than the average distance between the islands. If critical island radius is small compared to the average distance between the islands, they will nucleate a second layer before coalescence, giving multilayer growth. As a result the surface becomes rougher. Despite the many experimental and analytical studies performed, the reason of non-monotonous variation of surface roughness is not clear enough.

The purpose of this work is to explain non-mono- tonous dependences of the surface roughness as a function of substrate temperature and deposition flux. In our previous work [14] the model was proposed which explains the non-monotonous dependence of surface roughness on diffusivity of adatoms. In this study we consider the influence of substrate temperature and deposition flux to the surface roughness which shows nonmonotonous dependences in both cases (observed in many experiments). It is shown in this paper that despite both dependences being mathematically described by the same model, the explanation and physical reasons are different: diffusivity of adatoms strongly depends on substrate temperature (so the explanation is similar to that given previously [14]), but does not depend on deposition flux. To show this difference, both cases are analysed in this paper. For analysis some typical experimental results are taken from literature and qualitatively compared with calculated curves obtained by our model. Theoretical results show a good qualitative agreement with the experimental ones and allow explaining the physical origin of non-monotonous surface roughness variations with the substrate temperature and deposition flux.

\section{Kinetic model of island film growth}

Film growth can be divided into the following elementary steps: adsorption, diffusion of single atoms on the surface; nucleation of new clusters and coalescence. All these steps can be expressed by kinetic equations defining the time variation of surface coverage $\varphi$ and cluster density $n$. The main idea of the model is to separate the coverage of the first monolayer into coverage by single atoms $\varphi_{S}$ and by islands $\varphi_{C}$. This gives a possibility to include the processes of island nucleation and growth, coalescence, and other kinetic processes. More detailed description of the model can be found in our previous work $[15,16]$.

Thus, the kinetics of the first monolayer coverage by the single adatoms $\varphi_{S}$ may be obtained as

$$
\frac{\mathrm{d} \varphi_{S}}{\mathrm{~d} t}=\alpha_{A 0} i_{0}\left(1-\varphi_{L}\right)-\alpha_{A A} i_{0} \varphi_{S},
$$

where $t$ is the time, $i_{0}$ is the relative flux of arriving single atoms. The surface coverage $\varphi_{S}$ increases (the first term) due to the arrival of atom that sticks at the substrate surface with the sticking coefficient $\alpha_{A 0}$. The second term describes the decrease due to cluster nucleation process: an arriving atom sticks at the already existing single adatom with the probability $\alpha_{A A}$ and forms a new cluster of two atoms. $\left(1-\varphi_{L}\right)$ represents un- 
covered part of substrate which also involves diffusion length of single atoms $\lambda\left(\varphi_{L}=\varphi_{S}+\varphi_{C}+a(t) \varphi_{C}^{*}\right) \cdot \varphi_{C}^{*}$ is a dimensionless area with radius $\lambda$ (equal to diffusion length of adatoms) around the clusters within which the arrived atom will stick at the edge of the cluster. Because $\varphi_{L}$ involves the term $\varphi_{C}^{*}$ (will be precisely defined later in Eq. (8)) and at higher coverage may exceed 1, the normalization parameter $a(t)$ is introduced, which obtains the following values:

$$
a(t)= \begin{cases}1 & \text { if } \varphi_{L}<1 \\ \frac{1-\varphi_{S}(t)-\varphi_{C}(t)}{\varphi_{C}^{*}(t)} & \text { if } \varphi_{L} \geq 1\end{cases}
$$

The equation for the kinetics of substrate coverage by clusters $\varphi_{C}$ is the following:

$$
\begin{aligned}
\frac{\mathrm{d} \varphi_{C}}{\mathrm{~d} t}= & 2 \alpha_{A 0} i_{0} \varphi_{S}+a(t) \alpha_{A C} i_{0} \varphi_{C}^{*}+ \\
& +B^{(1)} \alpha_{A C} i_{0}\left(1-\varphi^{(1)}\right)\left(\varphi^{(1)}-\varphi^{(2)}\right) .
\end{aligned}
$$

The substrate coverage by clusters increases after the nucleation process (the first term), then after the atom sticks at the edge of already existing island with sticking coefficient $\alpha_{A C}$ (the second term), and when the atom jumps down from the top of an island because of the surface diffusion and sticks at the edge of the island (the third term). $B^{(1)}$ is the possibility of atom jumping down from upper monolayer to stick at the edge of island on the first monolayer. $\varphi^{(1)}, \varphi^{(2)}$ are the coverages of first and second monolayer, respectively.

The fourth equation presents the kinetics of the coverage of $K$ th $(>1)$ monolayer $\varphi^{(K)}$ :

$$
\begin{aligned}
\frac{\mathrm{d} \varphi^{(K)}}{\mathrm{d} t}= & A^{(K)} \alpha_{A T} i_{0}\left(\varphi^{(K-1)}-\varphi^{(K)}\right)+ \\
& +B^{(K)} \alpha_{A T} i_{0}\left(\varphi^{(K)}-\varphi^{(K+1)}\right) \\
& \times\left(\varphi^{(K-1)}-\varphi^{(K)}\right), \quad K=2,3, \ldots .
\end{aligned}
$$

The coverage of $K$ th monolayer increases when the atoms directly arrived remain on it (the first term) or because of the surface diffusion process (the second term) when atoms are jumping down from the upper monolayers. The possibility of the atom to stick on the top of the cluster or to jump down from it is defined by the coefficients $A^{(K)}$ and $B^{(K)}[15,16]$.
The kinetics of relative islands density $n$ is defined by the equation

$$
\frac{\mathrm{d} n}{\mathrm{~d} t}=\left\{\begin{aligned}
0.5 \alpha_{A A} i_{0} \varphi_{S}+\alpha_{\text {coal }} C_{\text {coal }}\left(1-\varphi_{S}-\varphi_{\beta}\right) \\
\quad \text { if } r<r_{\max }, \\
0 \quad \text { if } r \geq r_{\max } .
\end{aligned}\right.
$$

The density of islands $n$ increases because of nucleation (the first term) and decreases because of coalescence effect when two islands coalesce into a larger one as they touch each other with the probability $\alpha_{\text {coal }}$ (the second term). $C_{\text {coal }}$ is normalization factor (exact definition given in Ref. [15]) and $\varphi_{\beta}=n \beta^{2}+2 \beta \sqrt{n \varphi_{C}}$ is the dimensionless area around the island within the range of the migration radius $\beta$ of the island. When $\varphi_{\beta} \neq 0$, the islands can migrate, therefore the second term in Eq. (5) describes mobile coalescence effect.

The islands can contact mutually when the radius of the islands reaches the critical radius $r_{\max }$. It is assumed that at this moment the coalescence process stops (the second condition in Eq. (5)). If this happens the number of clusters remains constant. This also means the process of nucleation has stopped as well. The condition for physical contact of clusters was assumed to be the following:

$$
4 n r_{\max }^{2}=1 \text {. }
$$

The surface roughness $\delta(t)$ as a function of deposition time is defined as

$$
\delta(t)=P_{2}(t)-P_{1}(t),
$$

where $P_{1}(t)$ and $P_{2}(t)$ are the distances expressed in terms of the number of monolayers from the initial surface $(K=1)$ to the monolayer with the coverage equal to $\varphi\left(P_{1}(t)\right)=0.05$ and $\varphi\left(P_{2}(t)\right)=0.95$, respectively.

The atoms on the surface, before they are adsorbed, diffuse over the surface. The diffusion length $\lambda$ is included in the model through the term $\varphi_{C}^{*}$ in Eq. (3), and has the following form:

$$
\varphi_{C}^{*}=n \lambda^{2}+2 \lambda \sqrt{n \varphi_{C}} .
$$

Generally, the diffusion length is defined by relation $\lambda=\sqrt{4 D t}$, where $D$ is the diffusion coefficient. The diffusion length $\lambda\left(T_{\text {sub }}\right)$ as a function of the substrate temperature $T_{\text {sub }}$ can be expressed from Arrhenius law for diffusion $D=D_{0} \exp \left[-E_{\mathrm{a}} /\left(k T_{\text {sub }}\right)\right]$ :

$$
\lambda=2 \sqrt{D_{0} \exp \left(\frac{-E_{\mathrm{a}}}{k T_{\text {sub }}}\right) t},
$$

where $D_{0}$ is the preexponential constant, $E_{\mathrm{a}}$ is the surface diffusion activation energy, $k$ is the Boltzmann 


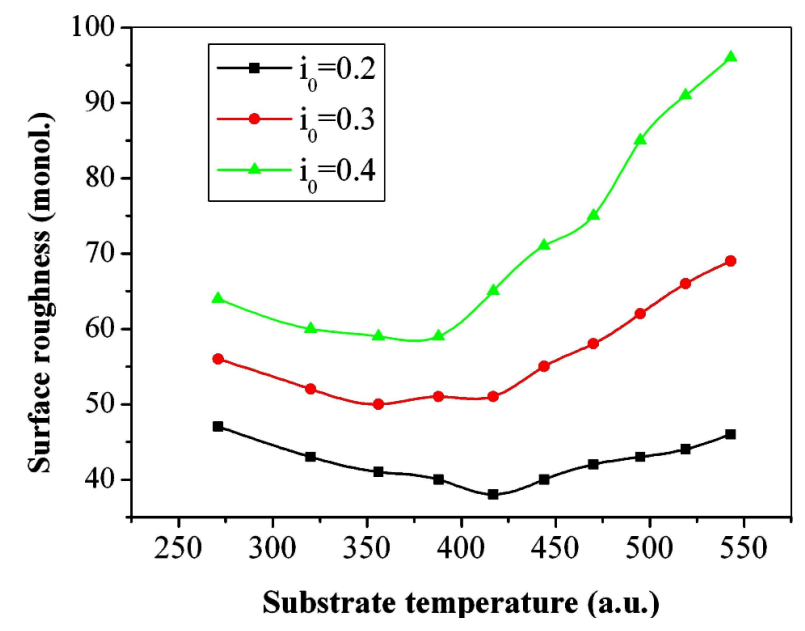

Fig. 2. Dependences of surface roughness on the substrate temperature in the cases of different flux of deposited atoms $i_{0}$. Coefficients used in calculations: $\alpha_{A 0}=0.1, \alpha_{A A}=0.0005, \alpha_{A C}=$ $0.1, \alpha_{A T}=1.0, \alpha_{\text {coal }}=0.0001, C=1, \beta=20, \lambda=\lambda_{T}$.

constant. The expression gives the increase of diffusion length with the substrate temperature.

\section{Results and discussion}

Single atoms arriving to the substrate diffuse over the surface until they nucleate into the new island or are trapped by existing islands. The nucleation of new islands depends on the surface diffusion activation barrier $E_{\mathrm{a}}$ and on the substrate temperature $T_{\text {sub }}$ (Eq. (9)).

The experimental results from Refs. [6, 11] presented in Fig. 1(a) show that the dependence of the surface roughness on the substrate temperature can be nonmonotonous. The modelling results presented in Fig. 2 show that the curve of surface roughness dependence on the substrate temperature passes a minimum value point when the temperature is increased. Figure 2 shows that our modelling results are qualitatively in a good agreement with experimental results of Fig. 1(a).

The non-monotonous dependence of the surface roughness on the substrate temperature can be explained by interplay between the island size and the diffusion length of adatoms (Fig. 3). The adatom diffusivity and the island sizes are negligible at low temperatures. Despite the small size of the islands, diffusivity of the adatoms is too low and the adatom cannot jump down from the top of islands. The adatoms arrived to the top of the island stick on it in this case. As a result the surface becomes rougher. The diffusivity of the adatoms and the size of islands increase as the temperature increases, yet the diameter of islands does not increase so fast and the atoms that have climbed onto the top of the islands could jump down to deeper layers. In this case

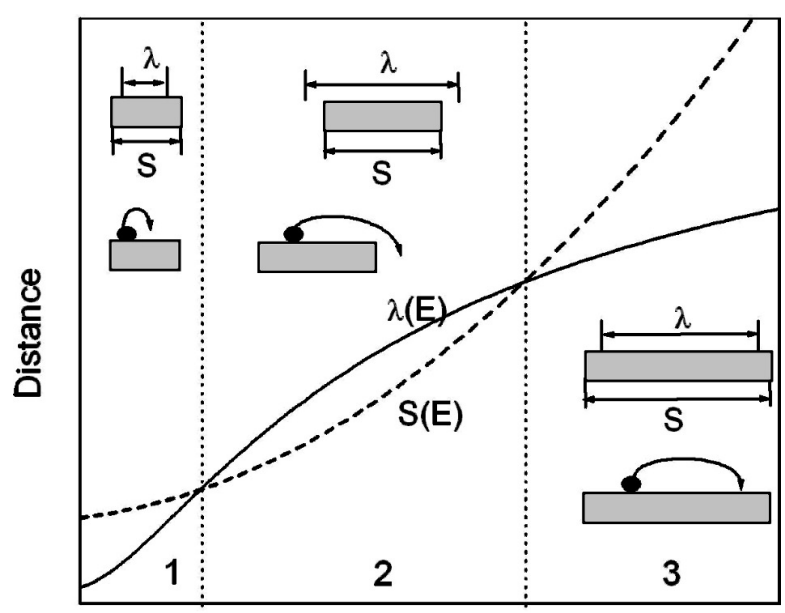

Energy of Adatoms

Fig. 3. Schematic drawing of the island size and diffusion length of adatoms and interplay between them, which explains the formation of non-monotonous dependence of surface roughness versus energy of the adatoms.

the surface becomes smoother. The size of the islands may exceed the adatom diffusion length again at higher temperatures. The atoms arrived to the island top layer remain on it and the surface roughness increases again.

The study of the surface roughness of a growing thin film as a function of substrate temperature and flux of arriving atoms was performed using the above kinetic model in two cases:

(i) the diffusion length of atoms on the pure substrate, $\lambda$, and on the deposited material, $\lambda_{T}$, are equal $\left(\lambda=\lambda_{T}\right)$;

(ii) the diffusion length of atoms on the pure surface, $\lambda$, is significantly higher than the diffusivity of adatoms on deposited material, $\lambda_{T}\left(\lambda \gg \lambda_{T}\right)$.

It is well known that at random deposition (random sticking of atoms) [17] the surface roughness $\delta$ increases with deposition time $t$ as its square root, $\delta \propto$ $\sqrt{t}$. The exact expression for the surface roughness can be found in that case, $\delta \propto \sqrt{4 \kappa t}$, where $\kappa$ is the adsorption rate: $\kappa=\alpha i_{0}$ ( $\alpha$ is sticking coefficient and $i_{0}$ is atomic flux). The intensity of flux acts in a similar way as duration of the deposition time: the number of the adsorbed atoms increases in both cases. Therefore, it follows that the surface roughness $\delta$ increases with the flux $i_{0}$ in the same manner as with the deposition time, i.e. $\delta \propto \sqrt{i_{0}}$. The calculated dependences of the surface roughness on the deposition flux in the case of $\lambda=\lambda_{T}$ are shown in Fig. 4, where the presented curves follow the law $\delta \propto \sqrt{i_{0}}$, i. e. the surface roughness monotonously increases with the deposition flux. However, the law $\delta \propto \sqrt{i_{0}}$ is valid for random 


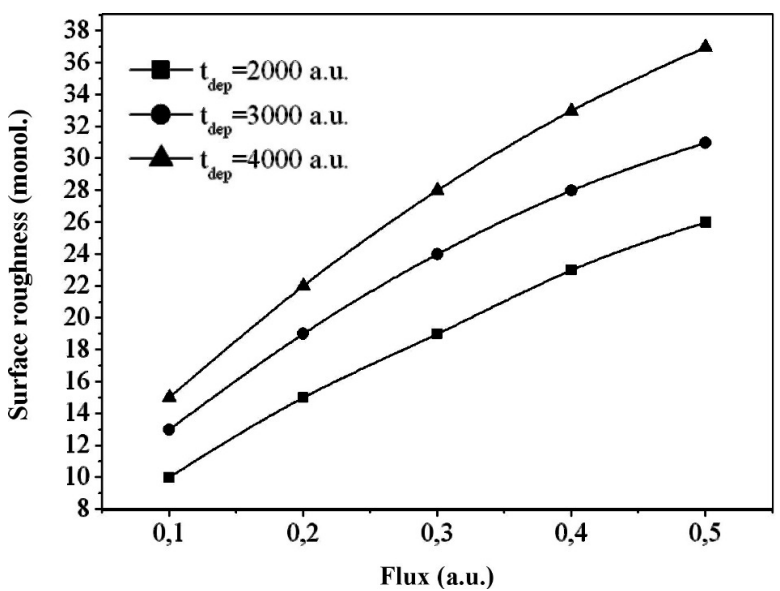

Fig. 4. Dependence of surface roughness on the flux of arriving atoms in the case $\lambda=\lambda_{T}$. Coefficients used in calculations: $\alpha_{A 0}=$ $0.05, \alpha_{A A}=0.005, \alpha_{A C}=0.1, \alpha_{A T}=1.0, \alpha_{\text {coal }}=0.001, C=$ $1, \beta=15, \lambda=\lambda_{T}=2$.

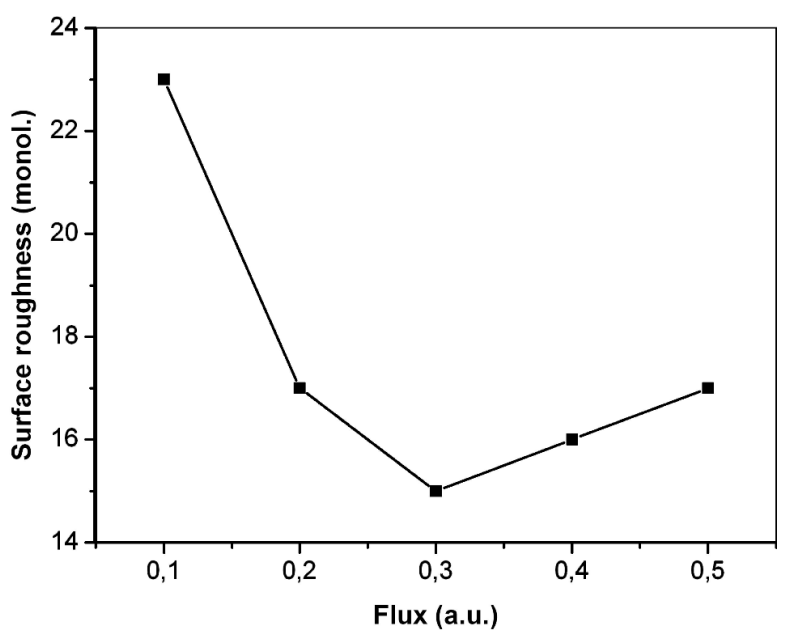

Fig. 5. Dependence of surface roughness on the flux of arriving atoms in the case $\lambda \gg \lambda_{T}$. Coefficients used in calculations: $\alpha_{A 0}=0.05, \alpha_{A A}=0.001, \alpha_{A C}=0.1, \alpha_{A T}=1.0, \alpha_{\text {coal }}=$ $0.0001, C=1, \beta=25, \lambda=30, \lambda_{T}=1$.

(no islands) sticking of arriving atoms only. In the case of driven sticking the deviation from this law is possible. The driven sticking means that the adsorption of atoms may be influenced by some driving forces under which some geometrical structures are formed. Island film growth belongs to the latter type.

The calculated dependence of the surface roughness on the deposition flux in the case of $\lambda \gg \lambda_{T}$ is presented in Fig. 5. The character of the curve is completely different from that presented in Fig. 4. The dependence is non-monotonous: the roughness decreases at the low fluxes and increases at the higher fluxes. The results of Fig. 5 are confirmed by Dumont's et al. experimental observations [11] for thin silver films deposited on mica substrate (Fig. 1(b)). The experimentally mea-

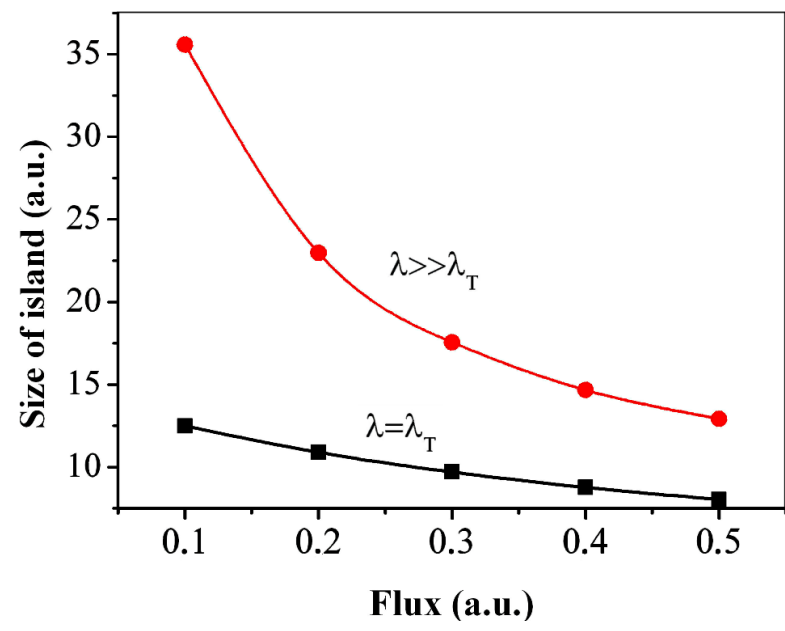

Fig. 6. Dependences of island size on the deposition flux in two cases, $\lambda=\lambda_{T}$ and $\lambda \gg \lambda_{T}$.

sured dependence of surface roughness on deposition rate shows the same behaviour (Fig. 1(b)).

As follows from the presented model, the decrease of roughness with increase of deposition flux occurs because of atomic jumps from the top of islands when diffusion length exceeds the size of island (regime 2 in Fig. 3). As shown in Fig. 6, where calculated dependences of the island size on deposition flux are presented, the size of islands decreases with increase of the deposition flux. The both curves, $\lambda=\lambda_{T}$ and $\lambda \gg \lambda_{T}$, show the same behaviour, but the island size in the case $\lambda \gg \lambda_{T}$ is significantly higher. In the case of larger islands, the decrease of island size gives more intense jumps of atoms from the top of islands to the substrate. As a result, the surface roughness decreases. However, the random sticking defined by the law $\delta \propto \sqrt{i_{0}}$ prevails again when islands become too small. The surface roughness starts to increase as it is seen in Fig. 5. Random sticking always takes place, tending to increase the roughness, whereas driven sticking is just an additional term which in the case of large islands reduces this tendency. Then the deviation from general law $\delta \propto \sqrt{i_{0}}$ occurs.

\section{Conclusions}

1. From the presented analysis the explanation of non-monotonous dependence of surface roughness on temperature is the following: (i) in the low temperature region the surface roughness decreases with temperature because the small island formation and atomic jumps from the top of islands onto the substrate prevail in this case; (ii) in the high temperature region large islands are formed and arriving atoms stick on the top of 
the islands, causing the surface roughness to increase with temperature.

2. The explanation of non-monotonous dependence of surface roughness on the deposition flux is the following. There is a general rule that the surface roughness at random deposition (no islands) increases with the deposition flux. However, there is a deviation from this rule if large islands are formed. Island size decreases with increasing deposition flux and the jumps of atoms down from the top of an island to the substrate become more intense. Then the decrease of the surface roughness takes place. At high flux, very small islands are formed and the jumps of atoms from the top of islands are not important. The random deposition regime prevails and surface roughness starts to increase with deposition flux.

\section{References}

[1] G. Knuyt, C. Quaeyhaegens, J. D'Haen, and L.M. Stals, A model for thin film texture evolution driven by surface energy effects, Phys. Status Solidi B 195, 179-193 (1996).

[2] J. Vaitkus, V. Kazlauskiene, J. Miskinis, and J. Sinius, $\mathrm{PbS}$ thin film formation on terrace-step surface by pulsed laser deposition, Mater. Res. Bull. 33, 711-716 (1998).

[3] J. Vaitkus, R. Baubinas, E. Gaubas, V. Kazlauskiene, J. Miskinis, A. Mazeikis, J. Sinius, E. Zasinas, and A. Zindulis, Cluster and thin layer of compound semiconductor growth on hexagonal and vicinal cubic surface and the simulation of atom behavior, Microelectron. J. 30, 335-340 (1999).

[4] Y. Kangawa, T. Ito, A. Taguchi, K. Shiraishi, T. Irisawa, and T. Ohachi, Monte Carlo simulation for temperature dependence of $\mathrm{Ga}$ diffusion lenght on GaAs(0 0 1), Appl. Surf. Sci. 190, 517-520 (2002).

[5] I. Volintiru, M. Creatore, and J.L. Linden, Expanding thermal plasma-deposited $\mathrm{ZnO}$ films: Substrate temperature influence on films properties. Film growth studies, Superlatt. Microstruct. 39, 348-357 (2006).
[6] S.G. Yoon, H.K. Kim, and M.J. Kim, Effect of substrate temperature on surface roughness and optical properties of $\mathrm{Ta}_{2} \mathrm{O}_{5}$ using ion-beam sputtering, Thin Solid Films 475, 239-242 (2005).

[7] P. Sobotík and I. Ošt'ádal, Temperature induced change of surface roughness of $\mathrm{Au}$ (111) epitaxial films on mica, J. Cryst. Growth 197, 955-962 (1999).

[8] M. Rusop, T. Soga, and T. Jimbo, The effect of processing parameters on amorphous carbon nitride layer properties, Diamond Relat. Mater. 13, 2187-2196 (2004).

[9] P. Patsalas, C. Gravalidis, and S. Logothetidis, Surface kinetics and subplantation phenomena affecting the texture, morphology, stress, and growth evolution of titanium nitride films, J. Appl. Phys. 96, 6234-6245 (2004).

[10] K. Cai, M. Müller, J. Bossert, A. Rechtenbach, and K.D. Jandt, Surface structure and composition of flat titanium thin films as a function of film thickness and evaporation rate, Appl. Surf. Sci. 250, 252-267 (2005).

[11] J. Dumont, F. Wiame, J. Ghijsen, and R. Sporken, Growth of atomically flat Ag on mica, Surf. Sci. 572, 459-466 (2004).

[12] G. Laukaitis, S. Lindroos, S. Tamulevičius, M. Leskelä, and M. Račkaitis, Stress and surface studies of SILAR grown $\mathrm{ZnS}$ thin films on (100) GaAs substrates, Mater. Sci. Eng. A 288, 223-230 (2000).

[13] P. Zhang, X. Zheng, S. Wu, and D. He, A computer simulation of nucleation and growth of thin films, Comput. Mater. Sci. 30, 331-336 (2004).

[14] A. Galdikas, Non-monotonous dependence of surface roughness on factors influencing energy of adatoms during thin island films growth, Surf. Sci. 600, 27052710 (2006).

[15] A. Galdikas, Thin film deposited onto the rough surface: Phenomenological investigations, Thin Solid Films 418, 112-118 (2002).

[16] A. Galdikas, Surface topography development and ion mixing in the study of depth profiling of multilayered structures, Vacuum 55, 51-58 (1999).

[17] A. Galdikas and L. Pranevičius, Interactions of Ions with Condensed Matter (Nova Science Publishers, Huntington, New York, 2000), p. 174. 


\title{
NEMONOTONINĖS PLONŲ DANGŲ PAVIRŠIAUS ŠIURKŠTUMO PRIKLAUSOMYBĖS NUO PADĖKLO TEMPERATŪROS IR NUSODINTŲ ATOMŲ SRAUTO
}

\author{
R. Čerapaitė-Trušinskienè ${ }^{\mathrm{a}, \mathrm{b}}$, A. Galdikas ${ }^{\mathrm{a}, \mathrm{b}}$ \\ ${ }^{\text {a }}$ Kauno technologijos universitetas, Kaunas, Lietuva \\ ${ }^{\mathrm{b}}$ Kauno medicinos universitetas, Kaunas, Lietuva
}

\section{Santrauka}

Paviršiaus šiurkštumas yra vienas iš svarbiausių parametrų, apibūdinančių plonas dangas. Yra daug eksperimentinių darbų, kuriuose nagrinejjama plonų dangų paviršiaus šiurkštumo priklausomybė nuo įvairių technologinių dangos auginimo parametrų: padèklo temperatūros, jonų energijos, dalelių srauto ir kt. Apibendrinant šiuos darbus, galima pasakyti, kad plonų dangu paviršiaus šiurkštumas, priklausomai nuo technologiniu parametrų kitimo, gali didèti, mažèti ar nekisti. Taip pat yra darbų, kuriuose stebima nemonotoninè paviršiaus šiurkštumo priklausomybè nuo padèklo temperatūros [6] bei dalelių srauto (nusodinimo greičio) [11]: paviršiaus šiurkštumo priklausomybe nuo šių dydžiu turi minimumo tašką.
Pasinaudojant kinetiniu modeliu $[15,16]$, tirta plonų dangų paviršiaus šiurkštumo priklausomybe nuo padèklo temperatūros bei i paviršiu krintančių daleliu srauto. Panaudotas kinetinis modelis, aprašantis salelini dangos augimą ir apimantis tokius procesus kaip adsorbuotų atomų paviršinè difuzija, nukleacija, susidariusių salelių augimas bei koalescencija. Modeliavimo rezultatai parodè, kad ir padèklo temperatūra, ir dalelių srautas veikia ant padèklo susidarančių salelių dydị, tuo pačiu ir plonų dangų paviršiaus šiurkštumą. Gauti modeliavimo rezultatai gerai sutampa su eksperimentiniais ir leidžia paaiškinti nemonotonini paviršiaus šiurkštumo kitimą. 